\title{
Growth hormone, prolactin and thyrotrophin responses to thyrotrophin-releasing hormone in diabetic patients
}

\author{
A. D. B. HARROWER \\ M.B., M.R.C.P. \\ Medical Unit, Monklands District General Hospital, Airdrie ML6 0JS
}

\begin{abstract}
Summary
Growth hormone (GH), prolactin (PRL) and thyrotrophin (TSH) responses to thyrotrophin-releasing hormone (TRH) were studied in 15 insulin-dependent diabetic patients. Basal plasma $\mathbf{G H}$ levels were raised above $5 \mathrm{mu}$./ 1 in 6 patients and following the injection of TRH there was a significant rise in plasma GH levels in 9. The mean rise in plasma GH from basal to peak values was significant in the group as a whole $(P<0.01)$.

Basal PRL and TSH levels were normal and rose normally in response to TRH.

GH release may be qualitatively abnormal in some diabetics and any such loss of specificity of GHreleasing mechanisms would further contribute to the raised GH levels found in many diabetics which would be of importance if $\mathrm{GH}$ is a factor in the aetiology of diabetic microangiopathy.
\end{abstract}

\section{Introduction}

In insulin-dependent diabetics, plasma growth hormone (GH) levels are usually elevated and show more frequent and higher peaks compared with nondiabetics (Hansen and Johansen, 1970; Corral et al., 1974). Plasma GH levels are also raised more easily in diabetics by stimuli such as exercise (Hansen, 1970, 1971), arginine (Passa, Rousselie and Ganville, 1977) and glucagon (Waldhausl et al., 1976). These quantitative differences in $\mathrm{GH}$ responses may partly explain the raised plasma GH levels in diabetics, but, in addition there may be qualitative differences in $\mathrm{GH}$ release as occurs in anorexia nervosa (Maeda et al., 1976; Harrower et al., 1977b) and chronic renal failure (Gonzalez-Barcena et al., 1973; Czernikow et al., 1976) where plasma GH levels are also often raised. In these conditions, thyrotrophin-releasing hormone (TRH) may stimulate $\mathrm{GH}$ release, an effect which does not occur in normal subjects, but which is similar to that reported in acromegalic patients (Irie and Tsushima, 1972; Luizzi et al., 1974; Gomez-Pan et al., 1975; Harrower et al., 1977a). If a similar effect occurs in diabetics then this would contribute further to GH release, ensuring that diabetic patients are exposed to high plasma GH levels for considerable periods of time.

To determine whether GH release in diabetics is modified by TRH, the author studied the effect of this hormone on plasma GH levels in a group of insulin-dependent diabetics. The effect of TRH on plasma prolactin (PRL) and thyrotrophin (TSH) levels was also investigated to ensure that an adequate stimulus had been given and also to determine whether PRL and TSH were released normally in response to this stimulus in such patients.

\section{Patients and methods}

Fifteen insulin-dependent diabetic patients $(9 \mathrm{M}$ and $6 \mathrm{~F}$ ) gave informed consent to the study. All were hospital in-patients at the time and clinical details are shown in Table 1. After an overnight fast an intravenous butterfly needle (Abbott) was inserted into a forearm vein at least $30 \mathrm{~min}$ before blood sampling began: the needle was kept patent with heparinized saline. In each patient, after a baseline sample had been taken, $500 \mu \mathrm{g}$ TRH (Roche) was injected and further blood samples taken after 20,30, 60 and $90 \mathrm{~min}$. Plasma was separated and stored at $-20^{\circ} \mathrm{C}$ for later analysis. All specimens were assayed for GH (Schalch and Parker, 1964), TSH (Irvine et al., 1973) and PRL (Reuter et al., 1976) by radioimmunoassay and for glucose with a Technicon autoanalyser using a glucose oxidase method. For the purposes of the study a 2-fold or greater rise in plasma GH was considered significant.

\section{Results}

Basal plasma GH levels were raised above 5 mu./1 in 6 patients (Table 2, nos 1, 4, 7, 10, 11 and 13). Following the injection of TRH, plasma GH levels rose significantly in 9 patients (nos $1-5,8$, 9,12 and 15). The rise in plasma GH from basal to peak levels was significant in the group as a whole $(P<0.01)$ (Fig. 1$)$ and the mean $( \pm$ s.e. mean) values at each time of sampling are shown in Fig. 2 and Table 2.

Basal plasma PRL levels were normal in all 15 
TABLE 1. Clinical data regarding age, sex, duration of diabetes and presence of complications in 15 diabetic patients

\begin{tabular}{|c|c|c|c|c|c|}
\hline Patient & Sex & $\underset{\text { (years) }}{\text { Age }}$ & $\begin{array}{l}\text { Duration } \\
\text { of diabetes } \\
\text { (years) }\end{array}$ & $\begin{array}{l}\text { Proliferative } \\
\text { retinopathy }\end{array}$ & Other diabetic complications \\
\hline 1 & $\mathbf{M}$ & 19 & 4 & - & - \\
\hline 2 & $\mathbf{M}$ & 30 & 17 & + & $\begin{array}{l}\text { Peripheral vascular disease, } \\
\text { Autonomic neuropathy }\end{array}$ \\
\hline 3 & M & 50 & 25 & + & $\begin{array}{l}\text { Peripheral vascular disease, } \\
\text { Autonomic neuropathy }\end{array}$ \\
\hline 4 & $\mathbf{F}$ & 17 & 7 & - & - \\
\hline 5 & $\mathrm{~F}$ & 19 & $<1$ & - & - \\
\hline 6 & $\mathbf{M}$ & 30 & 4 & - & - \\
\hline 7 & $\mathbf{F}$ & 15 & 5 & - & - \\
\hline 8 & $\mathbf{M}$ & 22 & 4 & - & - \\
\hline 9 & $\mathbf{F}$ & 58 & 2 & - & - \\
\hline 10 & $\mathbf{M}$ & 42 & $<1$ & - & Background retinopathy \\
\hline 11 & $\mathbf{M}$ & 44 & 12 & - & Background retinopathy \\
\hline 12 & $\mathbf{M}$ & 15 & 3 & - & - \\
\hline 13 & $\mathbf{F}$ & 62 & 11 & - & $\begin{array}{l}\text { Background retinopathy, } \\
\text { Somatic neuropathy }\end{array}$ \\
\hline 14 & $\mathbf{M}$ & 35 & 24 & + & Peripheral vascular disease \\
\hline 15 & $\mathrm{~F}$ & 18 & 7 & - & - \\
\hline
\end{tabular}

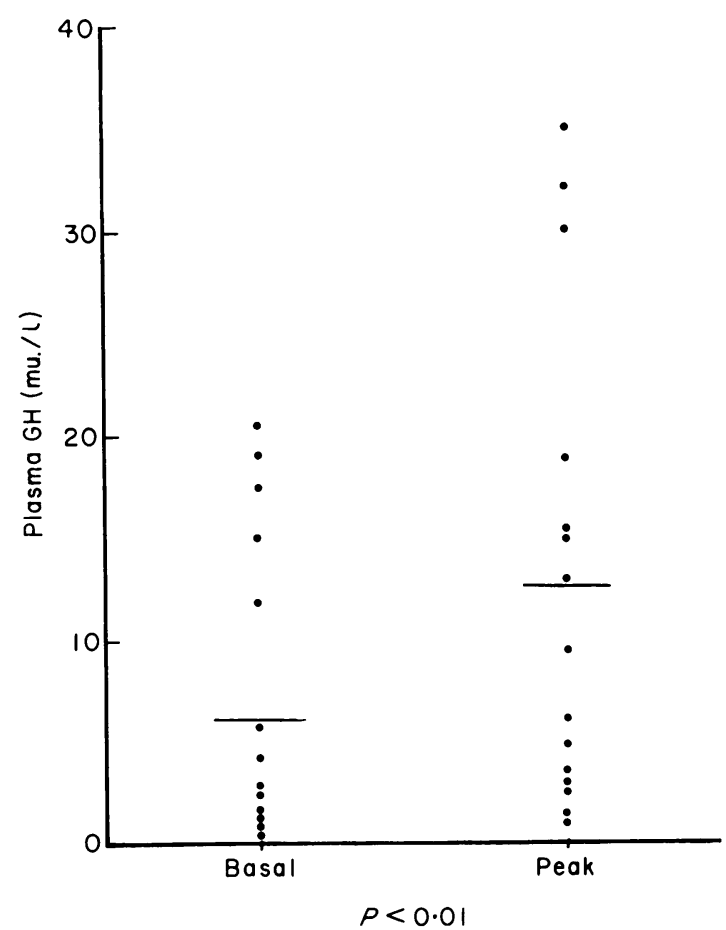

FIG. 1. Basal and peak plasma GH levels (mu./l) in 15 diabetic patients before and after injection of TRH $500 \mu \mathrm{g}$.

patients and rose normally in response to TRH (Fig. 3).

Basal TSH levels were also normal in all 15 patients and rose normally in response to TRH (Fig. 4).

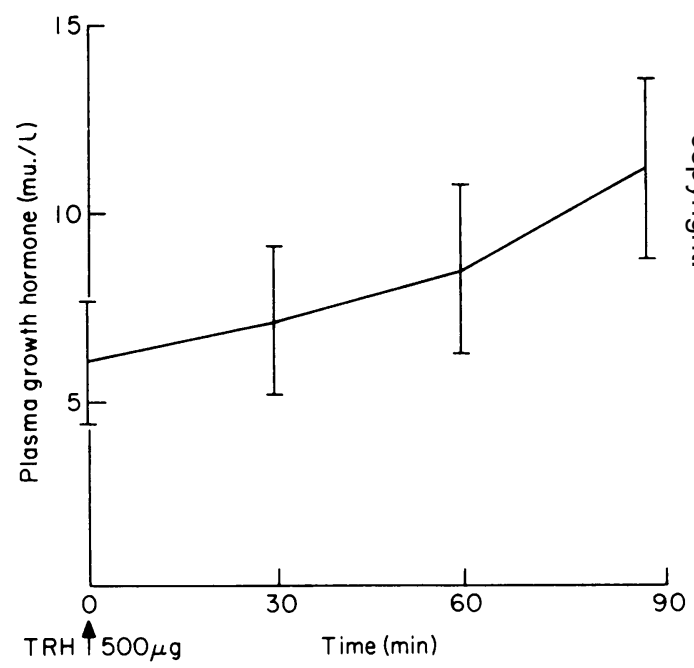

Fig. 2. Mean \pm s.e. mean plasma GH level (mu./l) in 15 diabetic patients before and after injection of TRH $500 \mu \mathrm{g}$.

Blood glucose levels ranged from $63-443 \mathrm{mg} / \mathrm{dl}$ (3.5-24.5 $\mathrm{mmol} / \mathrm{l})$, but did not change significantly in any patient during the procedure.

\section{Discussion}

The role of $\mathrm{GH}$ in the pathogenesis of diabetic microangiopathy has been debated since Houssay and Biassoti (1930) showed that hypophysectomy ameliorated diabetes. Pituitary ablation has been used to treat severe retinopathy with some success (Luft, Olwercroner and Sjögren, 1955; Joplin et al., 1965; Cullen et al., 1971; Kohner et al., 1976), 
and Lundbaek et al. $(1970,1971)$ have suggested a causal relationship between GH and the development of retinopathy in diabetics. This is also suggested by the report that retinopathy is worsened when GH is administered to pituitary-ablated patients (Ray et al., 1968). Secretion of GH is abnormal in some diabetics, plasma levels being elevated with more frequent and higher peaks compared to normal subjects (Corral et al., 1974). In addition, the patterns of $\mathrm{GH}$ response to different stimuli such

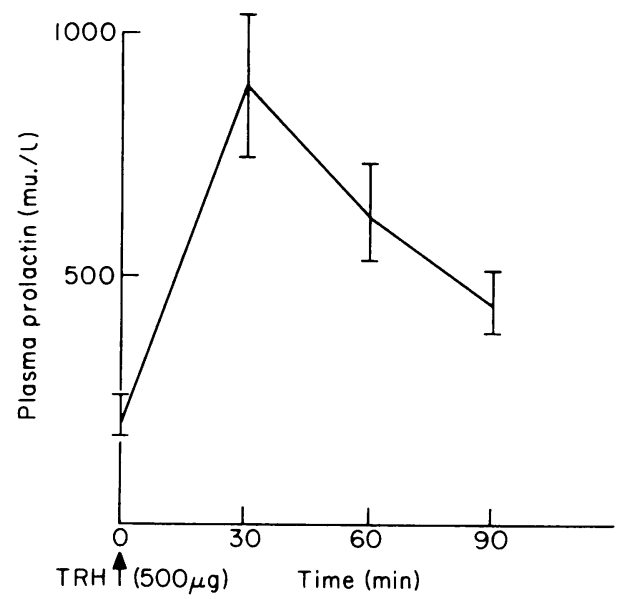

Fig. 3. Mean \pm s.e. mean plasma PRL levels (mu./1) in 15 diabetic patients before and after injection of TRH $500 \mu \mathrm{g}$.

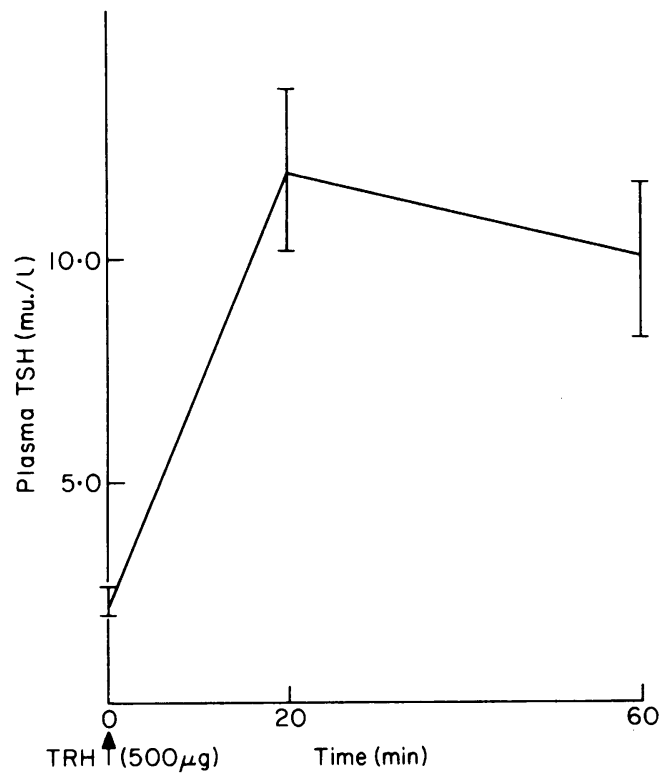

Fig. 4. Mean \pm s.e. mean plasma TSH levels (mu./l) in 15 diabetic patients before and after injection of TRH $500 \mu \mathrm{g}$. as exercise (Hansen, 1970; 1971), glucose loading (Knopf et al., 1973), arginine (Passa et al., 1977), glucagon (Waldhausl et al., 1976) and the suppressive effect of TRH on L-dopa-promoted GH release (Dølva, Torjesen and Hanssen, 1976) are normal in diabetics. It is also possible that in diabetes there is an altered sensitivity in the mechanism for $\mathrm{GH}$ release which allows various stimuli either to produce an exaggerated pattern of $\mathrm{GH}$ release or, as with TRH, to promote release of $\mathrm{GH}$, an effect which does not occur normally.

TABle 2. Plasma GH levels (mu./l) in 15 diabetic patients before and after injection of TRH $500 \mu \mathrm{g}$

\begin{tabular}{ccccc}
\hline & \multicolumn{4}{c}{ Time (min) after TRH } \\
\cline { 2 - 5 } Patient & 0 & 30 & 60 & 90 \\
\hline 1 & 5.34 & 10.7 & $35 \cdot 3$ & 21.7 \\
2 & 2.96 & 3.75 & 3.4 & 13.0 \\
3 & 0.75 & 0.79 & 0.75 & 3.59 \\
4 & 14.9 & 6.12 & 1.15 & 29.9 \\
5 & 2.6 & 5.66 & 9.33 & 9.52 \\
6 & 0.87 & 0.87 & 0.87 & 0.87 \\
7 & 18.9 & 32.0 & 20.9 & 28.0 \\
8 & 1.3 & 1.1 & 3.12 & 5.06 \\
9 & 0.67 & 2.62 & 2.07 & 2.96 \\
10 & 5.87 & 5.44 & 5.46 & 6.25 \\
11 & 17.6 & 13.1 & 15.4 & 5.48 \\
12 & 4.2 & 6.9 & 9.9 & 15.0 \\
13 & 12.0 & 11.0 & 3.2 & 2.4 \\
14 & 1.5 & 2.2 & 2.3 & 2.0 \\
15 & 1.6 & 3.3 & 12.0 & 19.0 \\
Mean & 6.07 & 7.04 & 8.34 & 10.98 \\
s.e. mean & 1.67 & 1.97 & 2.39 & 2.43 \\
\hline
\end{tabular}

Plasma GH levels were significantly raised above the basal level in response to TRH in 9 patients. The peak response was achieved after 30,60 and $90 \mathrm{~min}$ in one, 2 and 6 patients respectively (Table 2) and, although blood sampling was not continued after $90 \mathrm{~min}$, it is unlikely that a response occurring after this time could be attributed to the effect of TRH. The effect of TRH on GH release appears to be variable and is certainly less definite than on TSH or PRL release. It was not related to the presence of specific diabetic complications or blood glucose levels during the test. While plasma GH levels fluctuate spontaneously in both normal and diabetic subjects it is unlikely that the changes of the magnitude found in these patients could be attributed to this alone. Control plasma GH measurements without TRH injection over the same time period would have clarified this possibility. Previous diabetic control may be important, but reliable information such as that provided by $\mathrm{HbA}_{1} \mathrm{C}$ levels was not available at the time.

Basal PRL levels and the response to TRH were normal in all 15 patients suggesting that PRL has little part to play in the control of diabetes. 
Basal TSH levels and the TSH responses to TRH were also normal, confirming that the stimuli were adequate and that thyroid function was normal.

It appears, therefore, that in some diabetics GH release is qualitatively abnormal and any such loss of specificity of GH-releasing mechanisms could contribute to the raised plasma GH levels found in many diabetics. If $\mathrm{GH}$ is a factor in the pathogenesis of microangiopathy (Lundbaek, 1976) then such diabetics would be even more likely to be exposed to high plasma GH levels for long periods of time with adverse consequences.

\section{References}

Corral, R.J., Hunter, W.M., Campbell, I.W., Harrower, A.D.B., Duncan, L.J.P. \& Clarke, B.F. (1974) Reversal by insulin treatment of abnormal growth hormone pattern in newly diagnosed diabetes mellitus. Acta endocrinologica, 77, 115.

Cullen, J.F., Gibson, P.F., MacCuish, A.C., Harris, P., Donaldson, A.A., Munro, J.F. \& Duncan, L.J.P. (1971) Pituitary gland ablation by yttrium 90 implantation for advancing diabetic retinopathy. British Journal of Ophthalmology, 55, 217.

Czernichow, P., Dauzet, M.C., Broyer, M. \& Rappaport, R. (1976) Abnormal TSH prolactin and growth hormone response to thyrotrophin-releasing factor in chronic renal failure. Journal of Clinical Endocrinology, 43, 630.

Dølva, Ø., Torjesen, P.A. \& Hanssen, K.F. (1976) The suppressive effect of TRH on L-dopa promoted growth hormone release in healthy subjects and juvenile diabetics. Diabetologia, 12, 386.

Gomez-Pan, A., Tunbridge, W.M.G., Duns, A., Hall, R., Besser, G.M., Coy, D.H., Schally, A.V. \& Kastin, A.J. (1975) Hypothalamic hormone interaction in acromegaly. Clinical Endocrinology, 4, 455.

Gonzalez-Barcena, D., Kastin, A.J., Shalch, D.S., Torres-Zamara, M., Perez-Pasten, E., Kato, A. \& Schally, A.V. (1973) Response to TRH in patients with renal failure and after infusion in normal man. Journal of Clinical Endocrinology, 36, 117.

HANSEN, A.P. (1970) Abnormal serum growth hormone response to exercise in juvenile diabetics. Clinical Investigation, 49, 1467.

HANSEN, A.P. (1971) Normalisation of growth hormone hyperresponse to exercise in juvenile diabetics after 'normalisation' of blood sugar. Clinical Investigation, 50, 1806.

Hansen, A.P. \& Johansen, K. (1970) Diurnal patterns of blood glucose, serum free fatty acids, insulin glucagon and growth hormone in normal and juvenile diabetics. Diabetologia, 6, 27.

Harrower, A.D.B., YaP, P.L., Davidson, N.McD., StePhen, P., NaIRN, I.M. \& Strong, J.A. (1977a) TRHinduced release of growth hormone in acromegaly in predicting the response to treatment with bromocriptine. Scottish Medical Journal, 22, 241.

Harrower, A.D.B., YaP, P.L., NAIRn, Isobel M., Walton, H.J., Strong, J.A. \& Craig, A. (1977b) Growth hormone, insulin and prolactin secretion in anorexia nervosa and obesity during bromocriptine treatment. British Medical Journal, 2, 156.
Houssay, B.A. \& Biassoti, A. (1930) Hypophysectomie et diabète pancréatique. Archives internationales de pharmacodynamie et de thérapie, 38, 250.

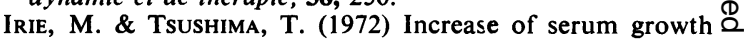
hormone concentration following TRH injection in $C$ patients with acromegaly and gigantism. Journal of Clinical Endocrinology, 35, 97.

Irvine, W.J., TofT, A.D., Hunter, W.M. \& KIRKhaM, D.E. $\overrightarrow{0}$ (1973) An assessment of plasma TSH immunoassay and of $\frac{C}{\sigma}$ the TSH-stimulation test in the diagnosis of 100 con- $\frac{\bar{O}}{\bar{N}}$ secutive patients with suspected hypothyroidism. Clinical $\frac{\Phi}{\vec{D}}$
Endocrinology, 2, 135 .

Joplin, G.F., Fraser, R., Hill, D.W., OAKley, N.W., صి SCOTT, D.J. \& DoYLE, F.H. (1965) Pituitary ablation for diabetic retinopathy. Quarterly Journal of Medicine, 34, $\overrightarrow{0}$ 443.

Knopf, R.F., Fajans, S.S., Pek, S., Floyd Jr, J.C., PrChkov, $\overrightarrow{\vec{\omega}}$ V.K. \& ConN, J.W. (1973) Plasma levels of growth hormone and glucagon in diabetic patients and relatives of $\vec{\partial}$ diabetic patients. In: Vascular and Neurological Changes in Early Diabetes (Ed. by R. Camerini-Davalos \& H. S. Cole) p. 215. Academic Press, New York, London.

Kohner, E.M., Hamilton, A.M., Joplin, G.F. \& Fraser, oু T.R. (1976) Florid diabetic retinopathy and its response of to treatment by photocoagulation or pituitary ablation. . Diabetes, 25, 104.

Luft, R., OlWercrona, H. \& Sü̈gren, B. (1955) Hypo- $\frac{\infty}{-}$ physectomy in man: experience in severe diabetes mellitus. 음 Clinical Endocrinology, 15, 391.

Luizzi, A., Chiodini, P.G., Botalla, L., Silvestrini, F. \& $\vec{c}$ Muller, E.E. (1974) Growth hormone releasing activity of TRH and growth hormone-lowering effects of dopaminergic drugs in acromegaly: homogeneity in the two $\vec{\bullet}$ responses. Journal of Clinical Endocrinology, 39, 871.

Lundbaek, K., Christensen, N.J., Jensen, V.A., Johansh

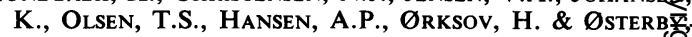
R. (1970) Diabetes, diabetic angiopathy and grow hormone. Lancet, ii, 131.

Lundbaek, K., Christensen, N.J., Jensen, V.A., Johansen, $\bar{\partial}$ K., OLSEN, T.S., HANSEN, A.P., ØRSKOV, H. \& ØSTER BY, R. 气 (1971) The pathogenesis of diabetic angiopathy and growth $\mathbb{D}$ hormone. Danish Medical Bulletin, 18, 1 .

Maeda, K., Kato, Y., Yamaguchi, N., Chihara, K., 产 Ohgo, S., IWASaki, Y., Yamamoto, Y., Modera, K., Э KwOMARU, S. \& IMURA, H. (1976) Growth hormone release $\underset{P}{ }$ following TRH injection in patients with anorexia nervosa. Acta endocrinologica, 81, 1.

Passa, P., Rousselie, F. \& Ganville, C. (1977) Retinopathy and plasma growth hormone levels in idiopathic hemochromatosis with diabetes. Diabetes, 26, 113.

Ray, B.S., Pazianos, A.G., Greenberg, E., Peretz, W.L. \& MCLeAN, J. (1968) Pituitary ablation for diabetic retinopathy: results of hypophysectomy (a ten-year evaluation). $\frac{\mathrm{O}}{3}$ Journal of the American Medical Association, 203, 79.

Reuter, A.M., Kennes, F., Gevaert, Y. \& Franchiment, 을 P. (1976) Homologous radioimmunoassay for human

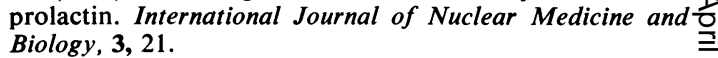

SChalCh, D.S. \& Parker, M.L. (1964) A sensitive double N antibody immunoassay for human growth hormone in plasma. Nature. London, 203, 1141.

Waldhausl, W., Dudczak, R., Freyler, H. \& Haydl, H. Nิ (1976) Serum growth hormone response to arginine, $\omega$ glucagon and exercise in diabetics with and without $\sigma$ retinopathy, in acromegalics and in normal subjects. Diabetologia, 12, 425. 